\title{
Treatment of Advanced Gastric Cancer: Where We Are in 2003
}

The issue of the effectiveness of systemic chemotherapy in metastatic gastric carcinoma engendered considerable debate during the late 1980s and early 1990s. Substantial scepticism existed as to whether or not chemotherapy had any advantages over best supportive care for patients with advanced gastric cancer. Four randomised trials have been reported that have addressed this issue using a randomisation of chemotherapy versus best supportive care. The data generated were rather consistent: chemotherapy improved median survival from 3 to 7 months $[1,2]$. These results strongly supported the use of chemotherapy in patients with metastatic gastric carcinoma, however, problems remain when defining the standard of care.

Different combinations of 5-FU, adriamycin, methotrexate, cisplatin and etoposide had given promising results. The first protocol which was considered as a standard of care was the FAMTX (5-FU + adriamycin + high dose methotrexate). This protocol was shown to give better results than the FAM protocol (5-FU + adriamycin + mitomycin C) in terms of response rate and survival. During the same period of time, two other active protocols were developed: combination of continuous infusion of 5-FU (5 days) + cisplatin (FP), and combination of 5-FU, etoposide and leucovorin (ELF). A large trial of the EORTC compared these different regimens. This trial gave very disappointing results with less than $25 \%$ of objective response rates in either of the three arms and no difference in terms of overall survival or toxicity [3]. A more recent British protocol used continuous infusion of 5-FU + cisplatin + epiadriamycin (ECF) and gave better results than FAMTX with no difference in terms of quality of life [4]. Consequently, the situation of first-line chemotherapy in gastric carcinoma remains a little bit confused and we are now waiting for the results of large phase III trials evaluating new agents such as irinotecan combined with 5-FU [5] or docetaxel + cisplatin [6]. The results of these two trials will be presented during the next meeting of the American Society of Clinical Oncology.
The situation of second-line treatment, which is the subject of the trial of Schmid et al. [7] in this issue of OnKOLOGIE, is even more complicated. With its relative chemosensitivity and the possibility of responses to 5 or 6 drugs, metastatic gastric carcinoma could be considered an ideal clinical situation for the determination of second-line treatment and strategic sequential applications in metastatic patients. However, the results of treatment with raltitrexed + oxaliplatin are disappointing and the authors themselves do not recommend the use of this combination. Poor results have also been observed in previous second-line treatments, whatever the type of schedules that have been used. An Italian study showed only one partial response with weekly docetaxel alone in 21 patients $(5 \%)$ and a very short median survival: 3.5 months [8]. Another Italian study used docetaxel alone given every 3 weeks in 24 patients. Three patients had a partial response (17\% of objective response) but 4 suffered from severe neutropenia [9]. A German study showed similar results, $12 \%$ of objective responses in 25 evaluable patients. Grade 4 neutropenia was often observed but the duration was very short and it was not life-threatening [10]. Very few studies have evaluated the efficacy of combined chemotherapy in second-line treatment. Combination of docetaxel and epi-adriamycin has resulted in $22 \%$ of objective responses in 23 patients, but produced $9 \%$ of febrile neutropenia [11]. Isolated cases of major responses to the combination of docetaxel + floxuridine in second- or third-line treatment have been published [12, 13].

Another way to improve the results of the treatment of metastatic gastric carcinoma would be to plan a sequential approach with change of the chemotherapy regimen before the appearance of the progression of the disease. An Italian trial evaluated this type of strategy. Forty patients received in first line a combination of 5-FU, folinic acid, epi-adriamycin and cisplatin (PELF regimen) followed by docetaxel in case of stabilisation or response. The response rate increased from $40 \%$ after the first line to $58 \%$ when treatment was completed, and median survival was 12.6 months [14].

\begin{tabular}{ll}
\hline KARGER & ○ 2003 S. Karger GmbH, Freiburg \\
$\begin{array}{ll}\text { Fax +49 761 4520714 } \\
\begin{array}{l}\text { E-mail Information@Karger.de } \\
\text { www.karger.com }\end{array}\end{array}$ & $\begin{array}{l}\text { Accessible online at: } \\
\text { www.karger.com/onk }\end{array}$ \\
&
\end{tabular}

Michel Ducreux, M.D., Ph.D. Institut Gustave Roussy

Unité de Gastro-Entérologie F-94805 Villejuif

Tel. +3314 211-4308 Fax -5228

E-mail ducreux@igr.fr 
It has also been tried to maintain response with new agents such as metalloprotease inhibitors. A large randomised phase III trial assessed this question: 184 patients received placebo and 185 marimastat, among them 60 patients in each arm have had a stabilisation or a response to first-line therapy. Survival was 167 days in the marimastat arm versus 135 in the placebo $\operatorname{arm}(p=0.07)$. This difference was not statistically significant, however, it seems that patients who have got positive results of their previous chemotherapy could benefit from maintenance with marimastat [15].

Another way to progress would be to define predictive factors of response and to adapt the profile of the chemotherapy to the profile of the tumour. Some biological markers have been shown to be predictive of better survival after surgical treatment or response to chemotherapy [16-18]. However, there is no sufficient evidence to recommend one of them in clinical practice.

In summary it is a long, long way to find new treatments of metastatic gastric cancer. However, even if the results of the current study are disappointing, efforts like those made by Schmid et al. should be encouraged to define in the future the strategy of treatment of this aggressive cancer.

Michel Ducreux and Valérie Boige, Villejuif

\section{References}

1 Glimelius B, Ekström K, Hoffman K, Graf W, Sjöden P-O, Haglund U, Svensson C, Enander LK, Linne T, Sellstrom H, Heuman R: Randomized comparison between chemotherapy plus best supportive care with best supportive care in advanced gastric cancer. Ann Oncol 1997;8:163-168.

2 Pyrhönen S, Kuitunen T, Nyandoto P, Kouri M: Randomised comparison of fluorouracil, epidoxorubicin and methotrexate (FEMTX) plus supportive care with supportive care alone in patients with non-resectable gastric cancer. Br J Cancer 1995;71: 587-591.

3 Vanhoefer U, Rougier P, Wilke H, Ducreux MP, Lacave AJ, Van Cutsem E, Planker M, Santos JG, Piedbois P, Paillot B, Bodenstein H, Schmoll HJ, Bleiberg H, Nordlinger B, Couvreur ML, Baron B, Wils JA: Final results of a randomized phase III trial of sequential high-dose methotrexate, fluorouracil, and doxorubicin versus estoposide, leucovorin, and fluorouracil versus infusional fluorouracil and cisplatin in advanced gastric cancer. A trial of the European Organization for Research and Treatment of Cancer Gastrointestinal Tract Cancer Cooperative Group. J Clin Oncol 2000;18: 2648-2657.

4 Webb A, Cunningham D, Scarffe JH, Harper P, Norman A, Joffe JK, Hughes M, Mansi J, Findlay M, Hill A, Oates J, Nicolson M, Hickish T, O'Brien M, Iveson T, Watson M, Underhill C, Wardley A, Meehan M: Randomized trial comparing epirubicin, cisplatin, and fluorouracil versus fluorouracil, doxorubicin, and methotrexate in advanced esophagogastric cancer. J Clin Oncol 1997;15:261-267.

5 Pozzo C, Szanto J, Peschel C, Popiela T, Gorbunova V, Zuber E, Di-Betta D, Alakl M, Jacques C, Baronius W: Irinotecan (Iri) in combination with CDDP (C) or with 5-FU and folinic acid (FU/FA) is active in patients (pts) with advanced gastric or gastroesophageal junction adenocarcinoma (AGC). Eur J Cancer 2000;11(suppl 4):63.
6 Ajani JA, Fodor M, Van Cutsem E, Tjulandin S, Moiseyenko V, Cabral F, Majlis A, Chao Y, Zuber E, Blattman A, Garay C, Jacques C: Multinational randomized trial of docetaxel $(\mathrm{T})$ and cisplatin $(\mathrm{C})$ with or without 5-fluorouracil (FU) in patients (pts) with advanced gastric or GE junction adenocarcinoma (AGC-AGEJC). Proc Am Soc Clin Onc 2000;19:247a.

7 Schmid KE, Kornerk GV, Schüll B, Raderer M, Lenauer A, Depisch D, Lang F, Scheithauer, W: Second-line treatment of advanced gastric cancer with oxaliplatin plus raltitrexed. Onkologie 2003; 26:255-258.

8 Graziano F, Catalano V, Baldelli AM, Giordani P, Testa E, Lai V, Catalano G, Battelli N, Cascinu S: A phase II study of weekly docetaxel as salvage chemotherapy for advanced gastric cancer. Ann Oncol 2000;11:1263-1266.

9 Giuliani F, Gebbia V, De Vita F, Maiello E, Gebbia N, Paoletti G, Coluci G: Docetaxel (Taxotere) as salvage chemotherapy in patients with advanced gastric cancer. A phase II study of the Southern Italian Oncology Group (GOIM). Ann Oncol 2000; 11:67.

10 Vanhoefer U, Harstrick A, Wilke H, Achterrath W, Preusser P, Stahl M, Fink U, Seeber S: Phase II study of docetaxel as salvage chemotherapy in patients with advanced gastric cancer. Eur J Cancer 1999;35: A529.

11 André T, Louvet C, Ychou M, Gamelin E, Mousseau M, Carola E, Assadourian S, de Gramont A: Docetaxel-epirubicin as second-line treatment for patients with advanced gastric cancer. Proc Am Soc Clin Onc 1999;18:277a.

12 Takizawa M, Hirano M, Murakami N, Uno Y, Kikuchi T, Nozawa H, Hara T, Asaumi Y, Kikkawa $\mathrm{H}$ : A case of recurrent gastric cancer that responded dramatically to docetaxel and 5'-DFUR combination chemotherapy. Gan To Kagaku Ryoho 2002; 29:1647-1650.
13 Mori T, Ikeda Y, Okamoto K, Sakata K, Ideguchi K, Nakagawa K, Yasumitsu T: A case of multiple skin metastases from gastric cancer successfully treated with docetaxel combined with doxifluridine. Gan To Kagaku Ryoho 2002;29:1451-1454.

14 Cascinu S, Graziano F, Barni S, Labianca R, Comella G, Casaretti R, Frontini L, Catalano V, Baldelli AM, Catalano G: A phase II study of sequential chemotherapy with docetaxel after the weekly PELF regimen in advanced gastric cancer. A report from the Italian group for the study of digestive tract cancer. Br J Cancer 2001;84:470-474.

15 Fielding J, Scholefield J, Stuart R, Hawkins R, McCulloch P, Maughan T, Seymour M, Van Cutsem E, Thorlacius-Ussing O, Hovendal C: A randomized double-blind placebo-controlled study of Marimastat in patients with inoperable gastric adenocarcinoma. Proc Am Soc Clin Onc 2000;19:240a.

16 Rha SY, Jeung HC, Roh JK, Kim JJ, Noh SH, Min JS, Kim BS, Chung HC: Biological phenotype determination with ex vivo model in gastric cancer for matrix-metalloproteinase inhibitor treatment. Int J Mol Med 2002;10:251-256.

17 Okuyama T, Maehara Y, Kabashima A, Takahashi I, Kakeji Y, Sugimachi K: Combined evaluation of expressions of p53 and p21 proteins as prognostic factors for patients with gastric carcinoma. Oncology 2002;63:353-361.

18 Karayiannakis AJ, Syrigos KN, Polychronidis A, Zbar A, Kouraklis G, Simopoulos C, Karatzas G: Circulating VEGF levels in the serum of gastric cancer patients: Correlation with pathological variables, patient survival, and tumor surgery. Ann Surg 2002;236:37-42. 